\title{
Impact of Biofield Energy Treatment on Soil Fertility
}

\author{
Mahendra Kumar Trivedi ${ }^{1}$, Alice Branton ${ }^{1}$, Dahryn Trivedi ${ }^{1}$, Gopal Nayak ${ }^{1}$, \\ Sambhu Charan Mondal ${ }^{2}$, Snehasis Jana ${ }^{2, *}$ \\ ${ }^{1}$ Trivedi Global Inc., Henderson, USA \\ ${ }^{2}$ Trivedi Science Research Laboratory Pvt. Ltd., Bhopal, Madhya Pradesh, India
}

Email address:

publication@trivedisrl.com (S. Jana)

\section{To cite this article:}

Mahendra Kumar Trivedi, Alice Branton, Dahryn Trivedi, Gopal Nayak, Sambhu Charan Mondal, Snehasis Jana. Impact of Biofield Energy Treatment on Soil Fertility. Earth Sciences. Vol. 4, No. 6, 2015, pp. 275-279. doi: 10.11648/j.earth.20150406.19

\begin{abstract}
Measurement of soil components such as microbial population, minerals and obviously the content of organic carbon play the important roles for the productivity of crops and plants. The present study was attempted to evaluate the impact of Mr. Trivedi's biofield energy treatment on soil for its physical (electrical conductivity), chemical (minerals) and microbial flora (bacteria and fungi). A plot of lands was assigned for this study with some already grown plants. This plot was divided into two parts. One part was considered as control, while another part was subjected to Mr. Trivedi's biofield energy treatment without physically touching and referred as treated. In the treated soil the total bacterial and fungal counts were increased by 546 and $617 \%$, respectively as compared to the untreated soil. Additionally, the conductivity of soil of the treated plot was increased by $79 \%$ as compared to the soil of control plot. Apart from microbes, the content of various minerals were also changed in the biofield energy treated soil. The calcium carbonate content showed $2909 \mathrm{ppm}$ in the control, while in the treated soil it was increased to $3943 \mathrm{ppm}$ i.e. $36 \%$ increased. Various other minerals such as nitrogen and potassium were increased by $12 \%$ and $7 \%$, respectively as compared to the control. Besides, the level of some minerals such as potassium, iron, and chloride were decreased by $9 \%, 23 \%$, and $41 \%$, respectively as compared to the control. Apart from chemical constituents of soil, the content of organic carbon was also reduced by $8 \%$ in the treated soil as compared to the control soil. The overall results envisaged that the biofield energy treatment on the soil showed a significant improvement in the physical, chemical, and microbial functions of soil component. Thus, improved the conductance, supportive microbes, minerals and overall productivity of crops. In conclusion, the biofield energy treatment could be used as an alternative way to increase the yield of quality crops by increasing soil fertility.
\end{abstract}

Keywords: Soil Fertility, Electrical Conductivity, Fungi, Bacteria, Minerals, Biofield Energy Treatment, Yield

\section{Introduction}

Soil is a vital natural resource. Our food system depends on a healthy terrestrial ecosystem, of which soil forms a vital component. Soil is not only a support for vegetation, but also provides a platform for numerous interactions between climate (water, air, temperature) and soil life (microorganisms, plants, animals) [1]. Soil bacteria and fungi play a vital role in various biogeochemical cycles (BGC) and are responsible for the transformation of organic compounds [2, 3]. Soil microorganisms also impart ecosystem by contributing nutrition and health of plants and exerted the soil structure and fertile ability [4]. However, many environmental activities; such as city development, agriculture, use of pesticides, and pollution can potentially affect soil microbial diversity that create an imbalance in the ecosystems. Soil nitrogen supply (SNS) is a key requirement for cereals and many other crops. It is important for both growers and agronomists, as it plays a key role of the decision-making process for optimizing nitrogen fertilizer doses [5]. Soil fertility depends on the availability of soil nutrient that can be assessed through chemical analysis. Apart from these, the physical and biological parameters are also crucial for soil fertility [6]. The nutrient and organic matter measurement in soil are too important than snapshot analysis and many agricultural researchers recommended the use of soil analysis with nutrient budgets for the assessment of fertility changes over time in organic systems $[7,8]$. There are many problems to find out microbial population in soil. One is the innate heterogeneity of soil containing many microhabitats that are suitable for microbial growth and thus of spatial distribution of the microorganisms $[9,10]$. 
A well-known physiologist, Willem Einthoven, in 1903 had developed electrocardiography (ECG) to measure the biofield of human body. Thus, human has the ability to harness the energy from environment or universe and can transmit into any living or nonliving object(s) around the Globe. The objects always receive the energy and responding into useful way that is called biofield energy and the process is known as biofield treatment. Harold Saxton Burr, had performed the detailed studies on the correlation of electric current with physiological process and concluded that every single process in the human body had an electrical significance. Recently, it was discovered that all the electrical process happening in body have strong relationship with magnetic field as required by Ampere's law, which states that the moving charge produces magnetic fields in surrounding space [11]. Thus, the human body emits the electromagnetic waves in form of bio-photons, which surrounds the body and it is commonly known as biofield. Therefore, the biofield consists of electromagnetic field, being generated by moving electrically charged particles (ions, cell, molecule etc.) inside the human body.

Any living body possesses some energy, and this energy can transformed from one form to another. Human body has a tremendous resource of certain kind of energy, responsible for physical, emotional or mental activities. Human can achieve this kind of energy from food, water and light. These are the main resources of life [12]. The National Center for Complementary and Integrative Health (NCCIH), recommended the use of CAM therapies like biofield energy as an alternative in the healthcare field. About $36 \%$ of US citizens regularly use some form of CAM [13], in their daily activities. In the year 2002, Korotkov K measured the human energy field level during CAM therapy with the help of computerized gas discharge visualization (GDV) technique based on Kirlian effect. They claimed it as a first tool to visualize the distribution of human's fields, more easily, reproducibly, graphically and, very inexpensive [14, 15].

A unique biofield treatment (The Trivedi effect ${ }^{\mathbb{B}}$ ) has known to alter growth and immunity in the field of agricultural science [16-19], chemical science [20], etc. To reduce the chances of nutrient deficiency disorders and increase the yield of crops. Moreover, to study the impacts of various factors such as microbial bioburden, mineral content and organic carbon on soil fertility the present work was undertaken to evaluate the effect of biofield energy treatment on soil.

\section{Materials and Methods}

An experiment on soil was designed at Dapoli, Maharashtra, India after harvesting cashew plants. The harvested plots were designated as control and treated. The treated part was subjected to Mr. Trivedi's biofield energy treatment. Soil samples were collected from two locations i.e. control and treated plot and were analyzed for bacterial, fungal, chemical, and physical parameters.

\subsection{Biofield Energy Treatment Strategy}

Mr. Trivedi provided the treatment to the plot assigned as treated through his inherent unique energy transmission process, while sitting on the ground close to the centre of the plot without physically touching the soil. The treated plot was not provided any pesticides, fungicides or organic additives other than water, whereas for the control plot, all the measures were supplemented as usual. After that, the soil sample was collected from both control and treated plots and analyzed.

\subsection{Analysis of Microorganism in Soil}

A serial decimal dilution was performed by adding approximately $10 \mathrm{~g}$ soil, wet weight, to $95 \mathrm{ml}$ of a $0.1 \%(\mathrm{w} / \mathrm{v})$ sodium pyrophosphate solution. Aliquots were transferred to the petri dishes containing specific media for counts of microbial groups. Total bacteria were counted using the medium of Bunt and Rovira. The same medium was used for the counts of Bacillus spp. spores after inoculation with diluted suspensions heated to $80-85^{\circ} \mathrm{C}$ in a water bath for $10 \mathrm{~min}$. The same medium supplemented with $5 \mu \mathrm{g}$ crystal violet was used for counts of Gram-negative bacteria. Fungi were counted in Martin medium supplemented with a mixture of penicillin and streptomycin $(0.1 \mathrm{~g} / \mathrm{L}, \mathrm{w} / \mathrm{v})$ and $70 \mu \mathrm{g} / \mathrm{mL}$ of rose bengal. Microbial counts were determined by the pour plate method after incubation of the cultures at $28^{\circ} \mathrm{C}$ for 4 days [21, 22].

\subsection{Analysis of Mineral in Soil}

Minerals are natural inorganic compounds with definite structure and properties. The soil minerals play an important role to find out the suitability of land for particular crops. All the specified minerals were analyzed as per internal protocol of therapeutics chemical research corporation (TCRC) [23].

\subsection{Analysis of Organic Carbon}

The Walkley-black procedure was followed for the estimation of organic carbon in soil samples [24]. The carbon content in soil was obtained with the help of following equation -

$$
\% C=\frac{M(V 1-V 2)}{S} 0.39 X m c f
$$

Where,

$\mathrm{M}=$ Molarity of ferrous sulphate solution (from blank titration); $\mathrm{V} 1=\mathrm{mL}$ ferrous sulphate solution required for blank; V2 = ml ferrous sulphate solution required for sample; $\mathrm{S}=$ Weight of air dry sample in gram; $0.39=3 \times 10^{3} \times 100 \%$ x 1.3 ( $3=$ Equivalent weight of carbon $) ; \operatorname{mcf}=$ moisture correction factor.

\section{Results and Discussion}

\subsection{Analysis of Microorganisms in Soil}

The total microbial counts i.e. bacteria and fungi are shown in Table 1. The total fungal count in control sample 
was found $5.3 \times 10^{2}$ colony forming unit (CFU) per gram of soil tested. Besides, in the treated soil the total fungal count was $3.8 \times 10^{3} \mathrm{CFU}$ per gram of soil tested. The study data indicated that there was $617 \%$ increase in the fungal count in the biofield energy treated soil as compared to the control soil. Additionally, the total bacterial count was $1.95 \times 10^{5}$ CFU in the untreated soil, while in the treated sample it was $1.26 \times 10^{6} \mathrm{CFU}$. The result indicated that there was $546 \%$ alteration of the bacterial population in treated soil as compared to the control.

Table 1. Total microbial counts (bacteria and fungi) in soil sample.

\begin{tabular}{llll}
\hline Characteristic & Control (CFU) & $\begin{array}{l}\text { Treated } \\
\text { (CFU) }\end{array}$ & $\begin{array}{l}\text { Percent } \\
\text { change }\end{array}$ \\
\hline Fungus/gm & $5.3 \times 10^{2}$ & $3.8 \times 10^{3}$ & $617 \uparrow$ \\
Bacterial count/gm & $1.95 \times 10^{5}$ & $1.26 \times 10^{6}$ & $546 \uparrow$ \\
\hline
\end{tabular}

CFU: Colony forming unit; $\uparrow:$ Increase

The soil from both the control and treated plots were analyzed for pathogens, fungus, and minerals. The results from the soil plot, where the treated crops and plants were also transformed. The level of pathogen and fungi in the soil was decreased. Pathogens infect the roots of the plants and absorb the nutrients from the roots. The soil also exhibited a significant increase in the supportive bacteria that is known to help the soil with nitrogen fixing, decomposition, increase the availability of nutrients and allow the plants to absorb more nutrients. There were plenty of literature reported the successional patterns of microbial content in the soil. Due to change of environmental conditions the microbial community is able to respond early because of the vastness of microbial biomass and diversity rather than plants that ultimately affect the ecosystem process such as carbon and nitrogen cycle [25]. Apart from conventional method for the analysis of microbial population, random matrix theory-based algorithms have been used to analyze the soil microbial communities from macro datasets, which are more sensitive, reliable, and robust [26].

\subsection{Analysis of Minerals in Soil}

The analysis of physical nature i.e. electrical conductivity and chemical composition were estimated and are shown in Table 2. The electrical conductance was performed in $10 \%$ solution of soil. In control soil the electrical conductivity was observed as $0.132 \mathrm{~ms} / \mathrm{cm}$, while in the treated sample it was found as $0.236 \mathrm{~ms} / \mathrm{cm}$. It was noticed that about $79 \%$ electrical conductivity was changed in the treated soil as compared to the control. Apart from physical nature, the essential minerals present in the soil are also equally responsible for the growth and development of crops. In this experiment the mineral content in both the control and treated soils were also analyzed and presented in Table 2. After analysis, in control sample the quantity of calcium carbonate $\left(\mathrm{CaCO}_{3}\right)$ was found as 2909 parts per million (ppm), while in the treated soil the content was $3943 \mathrm{ppm}$. There was $36 \%$ increase in the level of $\mathrm{CaCO}_{3}$ in the biofield energy treated sample as compared to the control sample. Moreover, nitrogen $(\mathrm{N})$ content was observed as
$0.17 \%$ in the control sample, whereas in the treated soil it was $0.19 \%$. After biofield treatment, the content of nitrogen in the soil was increased by $12 \%$ with respect to the untreated soil. Additionally, the potassium $(\mathrm{K})$ content in the treated soil was measured as $0.42 \%$ as compared to the control soil i.e. $0.45 \%$. Here, the $\mathrm{K}$ content was also increased by $7 \%$ as compared to the control. The phosphorus (P) level was found as $535 \mathrm{ppm}$ in the control sample, however in the treated sample it was $485 \mathrm{ppm}$. The data indicated that there was a reduction of $\mathrm{P}$ level by $9 \%$ in treated soil as compared to the untreated soil. Afterward, the iron (Fe) content was found as $14.39 \%$ in the control sample, whereas $11.14 \%$ was observed in the treated sample. In addition, the level of chloride $(\mathrm{Cl})$ was found as $0.017 \%$ in the control soil, while in the treated soil it was $0.01 \%$. It showed the chloride content was reduced by $23 \%$ in the treated soil as compared to the control.

Table 2. Physical and chemical analysis of soil minerals.

\begin{tabular}{llll}
\hline Characteristic & Control & Treated & Percent change \\
\hline $\begin{array}{l}\text { Electrical conductivity } \\
(10 \% \text { solution) ms/cm }\end{array}$ & 0.132 & 0.236 & $79 \uparrow$ \\
$\begin{array}{l}\text { Calcium carbonate } \\
\left(\mathrm{CaCO}_{3}\right) \text { ppm }\end{array}$ & 2909 & 3943 & $36 \uparrow$ \\
Nitrogen (N) \% & 0.17 & 0.19 & $12 \uparrow$ \\
Potassium (K) \% & 0.42 & 0.45 & $7 \uparrow$ \\
Phosphorus (P) ppm & 535 & 485 & $9 \downarrow$ \\
Iron (Fe) \% & 14.39 & 11.14 & $23 \downarrow$ \\
Chloride \% & 0.017 & 0.01 & $41 \downarrow$ \\
\hline
\end{tabular}

ppm: Parts per million; ms/cm: Milli-second/centrimeter; $\downarrow$ : Decrease; $\uparrow$ : Increase

\subsection{Analysis of Organic Carbon}

After estimation of the total microbial counts and the minerals components in the soil sample the organic carbon content was also analyzed and shown in Table 3. The percentage of organic carbon was $1.5 \%$ in the control soil, whereas in the treated soil it was observed as $1.38 \%$. The resulted data indicated that there was $8 \%$ reduction in the organic carbon content in the biofield energy treated soil as compared to the control.

Table 3. Percentage of organic carbon in soil sample.

\begin{tabular}{llll}
\hline Characteristic & Control & Treated & Percent change \\
\hline Organic carbon $\%$ & 1.5 & 1.38 & $8 \downarrow$ \\
\hline
\end{tabular}

$\downarrow$ : Decrease

It was observed that there has been depletion of some chemicals instead of negatively affecting the plant growth, the depletion has rather stimulated the plant growth and yield. Biofield energy treatment could be responsible to improve the physical, chemical and microbial population in the treated soil. It is assumed that these transformations of soil fertility might be helpful for metabolic activity, immunity and overall productivity of plants. Based on these results, it is expected that biofield energy treatment has the scope to be an alternative approach for improvement in the soil fertility by increasing the 
mineral content and reducing the load of microbes and decreased the level of organic carbon.

\section{Conclusions}

Based on the study outcome, the biofield energy treated soil showed better characteristics with respect to conductivity, microbial bioburden, and minerals as compared to the control. Moreover, the quality and fertility parameters were also improved in the treated sample. The fungal and bacterial content were increased by 617 and $546 \%$ in the treated sample as compared to the control. Besides, the conductivity of soil was increased by $79 \%$ in the treated soil with respect to control. The various essential minerals viz. calcium carbonate, nitrogen, and potassium were increased by 36,12 , and $7 \%$, respectively as compared to the control. Additionally, other minerals such as phosphorus, iron, and chloride level were also decreased by 9,23 , and $41 \%$, in the treated soil as compared to the control. Moreover, the content of organic carbon was also changed in the treated soil by $8 \%$ as compared to the control. In conclusion, the present investigation demonstrated that Mr. Trivedi's unique biofield energy treatment could be utilized as an alternate approach along with other existing approach to improve the productivity of crops by increasing the component of soil fertility in the field of agriculture.

\section{Abbreviations}

USDA: United States department of agriculture; BGC: Biogeochemical cycles; NCCIH: National center for complementary and integrative health; CAM: Complementary and alternative medicine; SNS: Soil nitrogen supply; GDV: Gas discharge visualization; TCRC: Therapeutics chemical research corporation; $\mathrm{CFU}$ : Colony forming unit; $\mathrm{CaCO}_{3}$ : Calcium carbonate; ppm: parts per million.

\section{Acknowledgements}

Financial assistance from Trivedi science, Trivedi testimonials and Trivedi master wellness is gratefully acknowledged. Authors thank Dr. Balasaheb Sawant Konkan Krishi Vidyapeeth, Maharashtra, India for their support.

\section{References}

[1] Janzen HH, Fixen PE, Franzluebbers AJ, Hattey J, Izaurralde RC, et al. (2009) Global prospects rooted in soil science. Soil Science Society of America Journal 75: 1-8.

[2] Likens GE, Bormann FH, Johnson NM (1981) Interactions between major biogeochemical cycles in terrestrial ecosystems. Some Perspectives of the Major Biogeochemical Cycles.

[3] Wall DH, Virginia RA (1999) Controls on soil biodiversity: Insights from extreme environments. Appl Soil Ecol 13: 137150 .
[4] Nandhini B, Josephine RM (2013) A study on bacterial and fungal diversity in potted soil. IGCMAS 2: 1-5.

[5] Chambers BJ, Richardson SJ (1993) Relying on soil mineral nitrogen reserves. J Sci Food Agr 63: 128-129.

[6] Stockdale EA, Shepherd MA, Fortune S, Cuttle SP (2002) Soil fertility in organic farming systems - Fundamentally different? Soil Use Manage 18: 301-308.

[7] Watson CA, Bengtsson H, Loes A-K, Myrbeck A, Salomon E, et al. (2002) A review of farm-scale nutrient budgets for organic farms as a tool for management of soil fertility. Soil Use Manage 18: 264-273.

[8] Oborn I, Edwards AC, Witter E, Oenema O, Ivarsson K, et al. (2003) Element balances as a tool for sustainable nutrient management: A critical appraisal of their merits and limitations within an agronomic and environmental context. Eur J Agron 20: 211-225.

[9] Duineveld BM, Rosado AS, van Elsas JD, van Veen JA (1998) Analysis of the dynamics of bacterial communities in the rhizosphere of the chrysanthemum via denaturing gradient gel electrophoresis and substrate utilization patterns. Appl Environ Microbiol 64: 4950- 4957.

[10] Franklin RB, Mills AL (2003) Multi-scale variation in spatial heterogeneity for microbial community structure in an eastern Virginia agricultural field. FEMS Microbiol Ecol 44: 335-346.

[11] Burr HS (1957) Bibliography of Harold Saxton Burr. Yale J Biol Med 30: 163-167.

[12] Korotkov K, Champs D (2005) Energie humaine. Resurgence Collection. Belgique.

[13] Barnes PM, Powell-Griner E, McFann K, Nahin RL (2004) Complementary and alternative medicine use among adults: United States, 2002. Adv Data 343: 1-19.

[14] Korotkov K (2002) Human energy field: Study with GDV bioelectrography. Fair Lawn, NJ: Backbone Publishing Co.

[15] Rubik B (2004) Scientific analysis of the human aura. In: Measuring energy fields: State of the art. GDV bioelectrography series. Korotkov K. (Ed.). Backbone Publishing Co. Fair Lawn, USA.

[16] Shinde V, Sances F, Patil S, Spence A (2012) Impact of biofield treatment on growth and yield of lettuce and tomato. Aust J Basic Appl Sci 6: 100-105.

[17] Sances F, Flora E, Patil S, Spence A, Shinde V (2013) Impact of biofield treatment on ginseng and organic blueberry yield. Agrivita J Agric Sci 35: 22-29.

[18] Lenssen AW (2013) Biofield and fungicide seed treatment influences on soybean productivity, seed quality and weed community. Agricultural Journal 8: 138-143.

[19] Nayak G, Altekar N (2015) Effect of biofield treatment on plant growth and adaptation. J Environ Health Sci 1: 1-9.

[20] Trivedi MK, Tallapragada RM, Branton A, Trivedi D, Nayak $\mathrm{G}$, et al. (2015) Characterization of physical, spectral and thermal properties of biofield treated 1,2,4-Triazole. J Mol Pharm Org Process Res 3: 128.

[21] Clark FE (1965) Agar-plate method for total microbial count. In Black C.A. et al., Eds. Methods of soil analysis. Part 2. Chemical and microbiological properties American Society of Agronomy, Madison, WI. 
[22] Martin JP (1950) Use of acid, rose bengal, and streptomycin in the plate method for estimating soil fungi. Soil Sci 69: 215232.

[23] Mahaney WC, Milner MW, Hs M, Hancock RGV, Aufreiter S, et al. (2000) Mineral and chemical analysis of soil eaten by humans in Indonesia. Int J Environ Health Res 10: 93-109.

[24] Nelson DW, Sommers LE (1982) in: Page USDA, SCS.
[25] Harris J (2008) Soil Microbial Communities and Restoration. Oikos 117: 1833.

[26] Lopez-Lozano NE, Heidelberg KB, Nelson WC, García-Oliva F, Luis E, et al. (2013) Microbial secondary succession in soil microcosms of a desert oasis in the Cuatro Cienegas Basin, Mexico. Peer J 1: e47. 